\title{
Isaiah 1:2-3, ethics and wisdom. Isaiah 1:2-3 and the Song of Moses (Dt 32): Is Isaiah a prophet like Moses?
}

\begin{abstract}
Author:
Alphonso Groenewald

Affiliation:

${ }^{1}$ Department of Old

Testament Studies,

University of Pretoria,

South Africa

Correspondence to:

Alphonso Groenewald

email:

alphonso.groenewald@

up.ac.za

Postal address:

Faculty of Theology,

University of Pretoria

Private Bag X20, Hatfield,

Pretoria 0083, South Africa

Dates:

Received: 07 Sept. 2010

Accepted: 21 Oct. 2010

Published: 07 June 2011

How to cite this article:

Groenewald, A., 2011,

'Isaiah 1:2-3, ethics and

wisdom. Isaiah 1:2-3 and

the Song of Moses (Dt 32): Is

Isaiah a prophet like Moses?',

HTS Teologiese Studies/

Theological Studies 67(1),

Art. \#954, 6 pages. DOI:

10.4102/hts.v67i1.954
\end{abstract}

(C) 2011. The Authors Licensee: OpenJournals Publishing. This work is licensed under the Creative Commons Attribution License.
This article argued that society even today could benefit from the richness of the ethics of the Hebrew Bible. Isaiah 1:2-3 has been used as an example to illustrate the ethics of a biblical text. This text has wisdom traits and literary links with Deuteronomy 32. In a modern, pluralistic society there is a need for a comprehensive ethical view by which one can combine a solid religious foundation, including responsibility towards God, the Creator and Lord of life, with a broad human wisdom gained from a rational understanding of the circumstances of existence for a true human life in a created world of order.

\section{Introduction}

Do the Hebrew Bible (HB) in general and the ethics of the HB in particular still have any normative significance for people in the 21st century? If one bears in mind the three millennia that separate ancient Israelite society from those of ours, the distance of time may just underscore the distance in matter (Sæbø 1998:162). The ethics of the HB focuses on the ethical reflection in the HB. It interprets the Hebrew texts from Israel's viewpoint of good behaviour, the possibilities it offers as well as its justification (Otto 1991:608). Theology and ethics are inseparable in the HB. The best way to understand and to apply the ethics of the Hebrew Scriptures is to try to put ourselves in the people of Israel's position and understand how they perceived and experienced their relationship with Yahweh, the God of Israel and also how that experience affected their ethical ideals and practical living as a community (Wright 2004:17). In terms of its aim, we can thus say an ethics of the HB should be descriptive.

Ethical systems display both a similarity as well as variety throughout the different epochs of history and in different cultures. The values and norms of the HB are not as such the proprium of Hebrew ethics, because they also feature in other ancient cultures, for example Egypt, Mesopotamia and Greece. The centre of Hebrew ethics rather should be sought in the idealistic framework and structure, which legitimises its values and norms. With regard to this idealistic structure of Hebrew ethics, the focus is primarily on the Pentateuch as the main source for its structure (Jensen 2006:20-24; Otto 2007a:26; cf. also Otto 1991:609-610, 1995:162; SchwienhorstSchönberger 2006b:908). The legal collections in the Torah form one of the pillars of a study of the ethics of the HB, specifically the system of legal and ethical rules which we find in the Decalogue (Ex 20:1-17; Dt 5:6-21), Covenant Code (Ex 20:22-23:33), Deuteronomic Law (Dt 12-26) and the Holiness Code (Lv 17-26).

Ethics, as a theory of morals, considers the maxims of conduct from the viewpoint of normative good and seeks its philosophical foundations as well as the consequences of good action (Otto 1999:1603, 2004:84). Of course, one should note that ancient Israel was a pre-philosophical society and culture (Barton 1994:12). In the HB there is no coherent reflection on ethics in the manner found in Western philosophical thought. Nevertheless, in the HB, whether at the level of individual books and sections of books, at redactional level or canonical level, we encounter more than just a mixture of isolated concepts with no underlying rationale. The ethical systems in the $\mathrm{HB}$ are generated by fundamental structures of ethical thinking.

Ethics makes us aware of aspects that implicitly govern action to the extent that action is morally qualifiable. In the ancient world of the eastern Mediterranean, moral action was characterised by a synthetic viewpoint of life; that is, it assumes a correspondence between people's experience of life and their deeds (Levin 2006:46; Otto 1999:1603, 2004:84). This is the point where sapiential thought becomes especially relevant for the ethics of the $\mathrm{HB}$, as it includes the notion of order in human life, that is, that moral conduct in accordance with ethical rules should lead to a good life (Otto 1995:167; Sæbø 1998:175-179; Zenger 2006:329). The ethical rules of the wisdom literature are, however, very distinct from those of the law codes. Its literary history was fundamentally connected to the theological discourse about the legitimisation of these rules and the consequences of ethical conduct (Otto 1995:166). It was only in the post-exilic period that wisdom in Israel, in contrast with for example wisdom thought in Egypt and Mesopotamia, went through a significant process of theologisation (Lange 2005:1367). 
Wisdom thought, especially the pre-exilic proverbs we have in the book of Proverbs 10-29, derives its ethical rules and regulations from the observation of structures of reason and consequence in nature and society (Lange 2005:1366-1367). If a specific action leads repeatedly either to a positive or to a negative outcome, the existence of some kind of a structure could be postulated. Sapiential ethics endeavours to recognise these structures, to adjust human actions accordingly and subsequently lay the basis for a positive and successful life. The structures ordering nature and society have their ontological basis in the creation of the world (SchwienhorstSchönberger 2006b:909). The wise thus know that only God has full knowledge of creation. He furthermore realises the limited character of his wisdom and that the fear of God was the beginning of all wisdom. Sapiential ethics strives to reach the balance between the natural order and moral conduct, as it was obvious to the wise that there was no other possibility in order to obtain a good life (Otto 1995:167).

In this context the prophets often grounded their accusations and their radical judgement of the people in a religiousethical manner (Sæbø 1998:173; Heschel 2001:288-289). Their preaching was legitimised as divine speech of revelation; but at the same time, they actualised the legal traditions in concrete applications. In addition, they even presented, again in a legal and ethical perspective, different elements of a boundary-breaking or universalistic preaching.

The book of Isaiah begins with a picture of the world in which Yahweh is the creator and the preserver of all things and thus occupies the supreme position over all that He has made. The essence of morality is co-operation in order to maintain the ordered structure that prevails under His guidance, in the natural constitution of things. The keynote of the whole system is order: a proper submission to one's assigned place in the scheme of things and the avoidance of any action that would challenge the supremacy of Yahweh, or seek to subvert the orders He has established (Barton 1995:90-91). This could be defined as the basic premise from which all of Isaiah's thinking about ethical obligation follows.

From this basic premise, one can thus define unethical behaviour as follows: it implies a disregard for order and is a deliberate refusal to see the world in its true colours. Folly, ignorance or perversity can be regarded as its most obvious manifestation. This moral blindness is culpable in itself, because it refuses to God the respect he deserves. It prefers the purposes of mere men to those of their creator; this is the root of other evil attitudes, which in their turn produce the specific sinful acts that distort human life. This produces a disregard for the orders in society that should mirror God's order. The practical effects of this failure are the crimes against social order: theft, murder, bribery and corruption, oppression of orphans and widows and enclosure of land. In the religious sphere it produces idolatry and a false confidence in the paraphernalia of cultic worship, which though apparently 'Yahwistic', is in fact self-centred. In the political sphere, we get a society that brings about its own downfall by its internal neglect of order and justice and its pursuit of self-interest and then seeks to protect itself by inventing religious rites that happen to suit its own taste (Barton 1995:90-91). It furthermore relies on other states that are in a condition of mental and moral confusion just as bad as its own for aid.

Isaiah shares many of the concerns of other prophetic books, such as the imperative of 'social justice' (Leclerc 2001:14-15). It, however, has its own preferred topics, which it condemns. Oppression of the poor is seen specifically as the expropriation of the land and miscarriage of justice (Barton 1997:69). Although most of these themes occur in other prophets (e.g. Amos and Micah), they are strongly concentrated in Isaiah and are linked, uniquely, to the political attitudes of the leaders of the Judean society. The interest Isaiah shows in the attitudes of his audience is scarcely to be found in the other prophetic books at all. The most obvious example is Isaiah's concern with human pride $(2: 12-19 ; 3: 1-5,3: 16-4: 1 ; 22: 15-19)$. Indeed, this is a kind of pride that leads them (his audience) to despise God's ways and only trust their own ways.

Humility towards God goes hand in hand with respect for the long-established orders of society. Isaiah's vision of society is one of a stable state, in which the exploitation of the poor, needy and disinherited, widows, orphans and other personae miserae by the ruling class is denounced. The key terms in his critique of society are 'justice' and 'righteousness' (Blenkinsopp 2000:108). For this to come about, the proper functioning of the judicial system is essential. Few acts are therefore denounced with such vehemence as the offering and the acceptance of bribes.

The distinctively Isaianic approach to ethics involves tracing ethical obligations to its highest source, which lies in the supremacy of God, from whom all good and all power derives; and doing, saying and thinking nothing which might derogate from that supremacy (Barton 1995:92, 1997:77; Jensen 2006:3). The way Yahweh acts towards Israel in benevolence or anger is rooted in the common theology of the Ancient Near East, which attributed success to the benevolence and disaster to the anger of the native deity. Isaiah's negative verdict upon Judah and Jerusalem is thus funded and reinforced by what must have been a shared conviction, which we also encounter in the book of Amos, that disregard of Yahweh's will in public life leads to subsequent trouble in public life. This ethical linkage constitutes the core of prophetic judgement (Brueggemann 1998:8-9). If this interpretation of Isaiah's ethical teaching is accurate, we have in him an early example of that way of approaching ethics that begins with a hierarchically ordered universe whose moral pattern is apparent to all humankind whose reason is not totally clouded and derives all particular moral offences from the one great fault, namely disrespect for natural order.

\section{Isaiah 1:2-3}

These verses provide the basic theme by which to enter the book. Because Yahweh is referred to in the third person in verse 4 , it seems that this discourse is limited to these two 
verses (Blenkinsopp 2000:182; Williamson 2006:23). The book of Isaiah opens with a complaint of Yahweh about the disloyalty of Israel. Heavens and earth (i.e. the whole creation) is called upon to listen and to bear witness to Yahweh's charge made against Israel, his people, his children, who, in spite of his loving care, rebel against him (Berges 1998:59; Childs 2001:17). The appeal to heaven and earth is a matter of the whole order of life.

This address to heaven and earth has a certain Deuteronomic resonance (Dt 32:1; cf. also 4:26; 30:19; 31:28; 32:1f.), suggestive of the condemnation or accusation following covenant violation based on a familiar pattern in treaties between the great powers and their vassals (Beuken 2003:70; Blenkinsopp 2000:182; Oswalt 1988:85). A similar cluster of topoi appears in the Deuteronomic Psalm 50:

- an appeal is made to heaven and earth to act as witnesses against faithless Israel (50:4)

- the covenant is linked with sacrifice (50:5)

- denunciation of worship divorced from moral conduct (50:7-23).

An entire historical tradition is summarised in Yahweh as the one who reared and cared for Israel in its formative period (cf. Hs 9:10-15; also with the verb גדל Pi'el). This text refers to God's relationship with Israel and uses the simple and natural image of parenthood (Beuken 2003:70). The terms 'reared' and 'brought up' adds a feminine nuance to the image of God (cf. Is 23:4; 49:21; 51:18; Hs 9:12). This view makes rebellion against God all the more unnatural: to refuse to submit to the one who has cared for you, is incomprehensible.

The unflattering contrast in verse 3 with an ox and a donkey also sets up the Hosean theme of Israel's failure to recognise God as its true benefactor (Hs 2:10 [Eng. 2:8]; cf. Dt 32:15). Israel, it seems, has less understanding of Yahweh than even the domesticated animals. The animal is completely dependent and unreservedly trusts the owner, who is completely trustworthy (Beuken 2003:71; Brueggeman 1998:13). This comparison, however, is in keeping with the didactics of the sages. They draw on the observation of nature, including animal behaviour, for rules for human conduct (Blenkinsopp 2000:182). These verses bear testimony to the same subject matter: Israel's total alienation from its God to whom it owes its life and well-being (Childs 2001:17). The focus, however, is not primarily Israel's unfaithfulness, but the merits of Yahweh's reaction towards Israel. Similarly to parents, who have taken care of their children and expect a thankful reaction from their side (Dt 21:18-21), Yahweh can expect such a reaction from Israel. By contrast, Israel refuses this relationship of trust upon which everything depends, namely the relationship which makes its life viable.

The rhetorical call for attention is one of the most characteristic stylistic features of prophetic criticism. The genre of this passage must be defined as the prophetic citation of Yahweh's accusation against Israel based on its characterisation as the prophet's transmission of a speech by Yahweh and the contents of the speech. Verses 2-3 are introduced with the vocative, the call to hear and give heed. The structure of these two verses can be indicated as follows (Kaiser 1981:27; Sweeney 1996:73):

- verse 2a: Introduction: summons of witnesses

- verse 2b-3: Accusation speech by YHWH against Israel (lament form).

Verses $2 b-3$ can be subdivided:

- Father speech: complaint against children for improper behaviour (v. 2b)

- Wisdom thought: Israel's lack of knowledge (v. 3).

\section{Isaiah 1:2-3 and Deuteronomy 32}

The initial formulaic appellation to the heavens and earth to bear testimony to God's accusations against Israel (Is 1:2) has its closest parallel in the first verse of the Song of Moses (Dt 32:1-43), ${ }^{1}$ which has been profiled with a narrative framework interpreting the call to heaven and earth to witness against Israel (Otto 2009:650-657). The text is hauntingly beautiful, even in translation and touched on well-known themes found elsewhere throughout the whole $\mathrm{HB}$ (Christensen 2002:785). Already in Deuteronomy 4:26 in direct speech God calls heaven and earth to testify against Israel, but in chapter 31 the theme of Israel's coming apostasy is expanded (Childs 2001:18).

The Song of Moses (or the so-called 'last words of Moses') calls upon the heaven and the earth to witness to God's faithfulness and Israel's corruption (32:4b-5). In the opening verses of Isaiah, similarly to the Song of Moses (Dt 32:28-29), Yahweh laments the fact that Israel lacks insight (Berges 1998:60). In fact, many of the themes of Isaiah are reflected in similar vocabulary in the Song of Moses (Childs 2001:18). The following examples in Deuteronomy 32 can be mentioned:

- Israel is a 'perverse nation' (v. 5, 20)

- 'children without faithfulness' (v. 20)

- 'with no understanding' (v. 28)

- 'from the vine of Sodom and from the fields of Gomorrah' (v. 32)

- God will punish them 'with a foolish nation' and 'scatter them afar' (v. 26)

- yet the one who 'wounds also heals' (v. 39) and 'will vindicate his people' (v. 36).

The author(s) of these introductory verses of Isaiah (1:2-3) did not want to scare off their audience anymore with the punishment, which is formulated in the book of Deuteronomy, because a terrible fate had already struck both the land as well as its inhabitants. The author(s) rather wanted to emphasise the effect of the divine word, which was not only meant for the opening section of the book of Isaiah, but rather formulated as a motto in view of the rest of the book of Isaiah (Berges 1998:60). A collapse in the covenantal relationship, because of disobedience, will activate the curses

1.No text within Deuteronomy has received more attention through the years than 1.No text within Deuteronomy has received more attention through the years than the Song of Moses from the ancient scribes who copied it to modern critical scholars
who consider its structure and significance. Compare Otto (2009:641-650) for an extensive overview of the history of research of the Song of Moses. 
that are formulated at the end of the Mosaic Torah. This seems to be the present situation. A link thus exists between Isaiah and the curses and blessings of Deuteronomy, which can only be dated in the post-exilic period as a possible historical situation befitting these statements. If there is this dependence, Isaiah is probably later (Williamson 2006:3132). There may thus have been several possible sources of influence, both from within the book of Isaiah and beyond, which contributed to this formulation.

The author(s) of this Isaianic text transformed Isaiah ben Amoz (v. 1) to a figure that is actualising the Mosaic Torah. The last words of biblical personages, whether Moses, David or Jesus, sum up their life and offer a historical resumé, often laden with theological significance (O'Kane 1996:33). Normally the last words point to the future as well as to the past; we thus get to know something of how the character wishes their life's work to be continued after death. In the case of Moses, his last words are further emphasised by their present canonical position at the end of the Pentateuch and before the book of Joshua. The death of Moses in Deuteronomy 34 acts as a transition from the Exodus and desert experience and, at the same time, Moses is also implicitly presented as the first in a series of prophets. The reason why Moses teaches the Song before his death is that in the future it may act as a witness against the people (Dt 31:19, 21) (O'Kane 1996:39). There is a feeling of certainty that the predicted troubles will take place; the Song will be a ruling against them because Moses (Dt 31:22) has taught it to them. The theme of witness is repeated in verse 24 , where the words of the Song become synonymous with the words of the law (Torah).

Revelation was profoundly under discussion in the late layers of the Pentateuch (Otto 2006:939). According to the postexilic Pentateuch and its theory of revelation, the revelation of God had ended with Moses' death (Dt 34:10-12). Access to God's Torah was only possible by interpretation of the Torah, which had already been explained in Deuteronomy, applied to Israel's life in the promised land and written down by Moses in the land of Moab (Dt 1:1-5; 31:913). In this sense Moses, according to the authors of the post-exilic Pentateuch, was not only the last prophet of Yahweh's direct revelation, but also the first scribe writing down the Torah and, very important, the first exegete of the Torah, which accompanied the people of Israel on their way into the promised land after Moses' death. In this sense, one can say that for the priestly authors of the post-exilic Pentateuch, Moses' task as prophet was revived in the written Torah.

The theory of revelation functioned entirely different within the post-exilic circles of prophetic literature (Otto 2006:939940). These circles were of the opinion that God's revelation had been continuing until their time, although they used the same scribal techniques of exegesis than the priests, not only for the explanation of the Mosaic Torah, but mainly of prophetic words. There were different prophetic schools of post-exilic prophetic tradents [tradentenprophetie], who followed the tradition of the different prophetic figures or discourse founders like Isaiah, Ezekiel or Jeremiah (Otto 2007b:161; Steck 1991:61-63, 167-170). Each of these schools also reacted, to a certain degree, to the priestly theories of revelation in the Pentateuch (cf. Sommer 1998:140-151). The post-exilic priestly authors of the Pentateuch described Moses as the arch-prophet, who had already predicted the exile as a consequence of Israel's disobedience and God's wrath (Otto 2006:940).

The formation of the Pentateuch and the corpus propheticum in post-exilic Jerusalem must have taken place in different discourse groups in which each one considered the position of the other (Berges 2008:13). The model of the discourse founder is particularly appropriate in the case of Isaiah ben Amoz, as the literary drama of the post-exilic new beginning anchors itself in him and his visionary power. Within this perspective, Isaiah is seen as a prophet in succession to Moses, whose main task is to speak the word of Yahweh as Deuteronomy makes clear:

I will raise up for them a prophet like you ... I will put my words in the mouth of the prophet, who shall speak to them everything that I command.

(Dt 18:18, NRSV)

Isaiah thus becomes the prophet who continues the teachings of Moses, a continuity that enhances his authority ( $\mathrm{O}^{\prime}$ Kane 1996:48). The opening words of his book is a witness against the people, as Moses' words were and these opening words even recall exact phrases spoken by Moses in Deuteronomy. The law, initially spoken by Moses, is continued in the words and teachings of Isaiah. The compilers of the book of Isaiah wished to represent Isaiah as someone who repeats and interprets Moses' words in a new setting.

\section{Isaiah 1:2-3, wisdom and ethics}

The problem of what constitutes wisdom or wisdom traditions has been debated over the years, but with little consensus (O'Kane 1991:67; Wilson 2009:150). ${ }^{2}$ Does the term hokmāh specifically indicate literary forms and genres, or does it refer to a social movement, a secular stance on life or merely the presence of intellectual traditions in Israel? In order to use 'wisdom' for this discussion of ethics, it is necessary to describe this phenomenon by listing its many aspects and functions in the Old Testament. According to Baumann (2009:17-19), the phenomenon 'wisdom' can be described with the help of the following aspects of 'sagacity or knowledge of man', or of human intelligence and knowledge:

1. magic and manticism

2. skill and ability

3. cleverness, slyness and cunning

4. practical wisdom

5. culture

6. rules of conduct

7. ethical conduct

8. piety

9. academic wisdom

10. eschatological blessing and apocalyptical endowment.

2.Cf. O'Kane (1991:67-74) and Wilson (2009:146-150) for a discussion of previous studies that have explored the connections between Isaiah and Wisdom. 
For the topic of ethics, not only 'ethical conduct' (7) in the narrow sense of the word is relevant, but also other aspects: skill and ability (2), cleverness, slyness and cunning (3), practical wisdom, or common sense (4), culture, or education (5), rules of conduct (6), piety, or religious conduct (8) and academic wisdom, or the teaching of wisdom (9).

The truly seminal study on the matter of wisdom influence in the book of Isaiah was that of Fichtner in 1949. He started his article by stating the following: In the spiritual history of Israel, there are few so completely antithetical phenomena as prophecy and hokmäh [wisdom]. Two worlds stand in total opposition: the proclaimer and admonisher who is seized by God and laid completely under claim and who carries out his lofty and dangerous mission to his people without any personal considerations. The clever and prudent worldlywise sage who goes his peaceable way cautiously looking right and left and who instructs his protégés in the same wise style of mastering life. He continues to ask whether it could be possible that the pre-exilic prophets were acquainted with the wise and entered into debate with them, learned from them or rejected them. Without question, there are various points at which the views of the pre-exilic prophets seem to be directly compatible with those of the wise sages of the book of Proverbs (Fichtner 1949:75).

In Isaiah, he found a unique relationship to wisdom. Firstly, Isaiah clearly turns against human wisdom, which overrates itself, disassociates itself from God and assails the wise of his own people and of other nations who go their own shrewd political ways without and therefore against God. On the other hand Isaiah himself clearly stands in the tradition of the wisdom-perspectives, exhibits various relationships, perhaps even literary dependency, to the wisdom literature and its forms. According to Fichtner (1949:77) it even formulates his image of the future hokmatically.

The question would be whether we can give some kind of indication (even when very preliminary) whether Fichtner's (1949) observations hold any ground. In order to do this evaluation, the following approach can be helpful: can we explore whether wisdom forms are present in the text? In other words, can one identify the function that wisdom ideas play in evaluating and assessing the content of a particular passage opposed to merely identifying forms and vocabulary reminiscent of wisdom literature? This discussion will be restricted to Isaiah 1:2-3.

In this programmatic passage at the beginning of the book, an animal proverb is used to emphasise Israel's stupidity (Beuken 2003:71; Jensen 2006:117). It seems that especially the language used in verse 3 can indicate a wisdom background (Sweeney 1996:74). Observations of the natural world and the application of the principles observed to human life are particularly characteristic of wisdom. As is obvious, verse 3 illustrates and specifies the complaint of the betrayed father (Whedbee 1971:37). It seems that a wisdom pattern is employed here in the father-son relationship. The recipients of wisdom teaching are typically designated as 'sons' and the primary demand is for sons to hearken, to obey instruction. The book of Proverbs is laced with numerous examples:

- 'Hear, o sons, a father's instruction, and be attentive, that you may know insight' (4:1)

- 'My son, be attentive to my wisdom, incline your ear to my understanding' (5:1)

- 'My son, keep your father's commandment, and forsake not your mother's teaching' (6:20).

It is likely that Isaiah is utilising this sort of broad background in this parable in verse 3 :

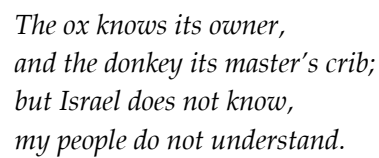

The proverbial stamp of verse 3a is self-apparent and belies the pedagogical interests of the speech. The picture of animal behaviour is common in wisdom. Moreover, the ass and ox frequently appear in Ancient Near Eastern wisdom. Both were favourite subjects for markers of proverbs and were known especially for their stupidity and streaks of contrariness (Pr 7:22-23; 26:3). However, Isaiah's use of the ass and ox motif goes against the normal wisdom tradition. It is particularly effective because they are put in a positive light in order to contrast with Israel's behaviour, especially when one thinks of the characteristics that are normally assigned to them (Whedbee 1971:40). Even when compared with animals, Israel comes off a poor second: the ironic implication is painfully clear.

Isaiah thus depicts Israel's sinfulness in terms of a breakdown in the basic order of the world. Israel's behaviour is anything but wise; in fact, it does not even measure up to the behaviour one can expect from animals. Isaiah thus transposes the wisdom understanding of the world into a special key, for he portrays the basic order in terms of the Yahweh-Israel bond. However, the important matter is that Isaiah characterises the Yahweh-Israel bond according to wisdom categories: like the wise men, Isaiah's intention is to highlight the blatant unnaturalness of Israel's sins.

Coming on the heels of the opening call to heaven and earth, the two indictments in verses $2 b$ and 3 show the rich complexity of Isaiah's language. Here in a skilful manner two different genres are combined, namely a complaint and a didactic parable and two different metaphors are used, namely father and son and ass and ox (Wilson 2009:153). There is a certain affinity between the two metaphors: both depend on imagery drawn from domestic life. Yahweh had 'reared and brought up' Israel as his son, but Israel had 'broken with' Yahweh, had run away the Father's house and was worse than domesticated animals. The sons lacked the wisdom of beasts of burden. Moreover, both metaphors serve to underscore the unnaturalness of Israel's behaviour.

It thus seems that wisdom or wisdom-like elements were incorporated in the book of Isaiah as wisdom observations 
resonated with the Judeans who knew that both wisdom and the wise were genuine parts of the Judahite society (Wilson 2009:163-164). It is thus not a matter of whether Isaiah has drunk from wisdom's stream; rather, wisdom's stream flows as part of a mixed water supply in Judah. Wisdom tradition was thus an integral part of Israelite religion and society, accessible to priest and prophet. Wisdom itself is thus a key component of the Israelite theology; therefore, many distinctively wisdom themes and concerns are part of the common stock of traditions in the Old Testament. If wisdom and its ideas had permeated the common cultural stock, this highlights that wisdom is already woven into the way of thinking of the prophets.

\section{Conclusion}

Isaiah begins with a picture of the world in which God is the creator and preserver of all things and occupies by right the supreme position over all that he has made (Barton 1995:90). The essence of morality is cooperation in maintaining the ordered structure that prevails under God's guidance in the natural constitution of things. The keynote of the whole system is order, a proper submission to one's assigned place in the scheme of things and the avoidance of action that would challenge the supremacy of God or seek to subvert the orders he has established. For Isaiah 'folly' is unwise and unethical. It is folly not to acknowledge Yahweh's supremacy. Such is the basic premise from which all Isaiah's thinking about ethical obligation begins. The discussion of the text of Isaiah 1:2-3 also highlighted this Isaianic principle.

It seems that even today we can benefit from the richness of the ethics of the Hebrew Bible. In a modern, pluralistic society there is a need for a comprehensive ethical view and attitude of this kind, by which one can combine a solid religious foundation, including responsibility towards God, the Creator and Lord of life, with a broad human wisdom gained from a rational understanding of the circumstances of existence for a true human life in a created world of order as demonstrated in the Hebrew Bible and Proto-Isaiah.

\section{Acknowledgement}

I would like to congratulate Prof. Andries G. van Aarde, New Testament scholar (University of Pretoria), as well as editor of the theological journal HTS Teologiese Studies/Theological Stufies, with his 60th birthday. He is not only a leading scholar to whom I owe a lot of respect, but also an example of a life lived ethically.

\section{References}

Barton, J., 1994, 'The basis of ethics in the Hebrew Bible', Semeia 66, 11-22.

Barton, J., 1995, 'Ethics in Isaiah of Jerusalem', in R.P. Gordon (ed.), 'The place is too small for us'. The Israelite prophets in recent scholarship, (Sources for biblical and theological study 5), pp. 80-97, Eisenbrauns, Winona Lake.

Barton, J., 1997, 'Ethics in the book of Isaiah', in C.C. Broyles \& C.A. Evans (eds.), Writing and reading the scroll of Isaiah. Studies of an interpretative tradition, (Vetus Testamentum, suppl. ser. 70, vol. 1), pp. 67-77, Brill, Leiden.

Baumann, G., 2009, 'Wisdom and Ethics - The contribution of sapiential ethics for Old Testament Ethics', Verbum et Ecclesia 30(1), 15-24.
Berges, U., 1998, Das Buch Jesaja: Komposition und Endgestalt, Herder, Freiburg. (HBS 16).

Berges, U., 2008, 'Das Jesajabuch als Jesajas Buch. Zu neuesten Entwicklungen in der Prophetenforschung', Theologische Revue 104(1), 3-14.

Beuken, W.A.M., 2003, Jesaja 1-12, Herder, Freiburg i.Br. (HThKAT).

Blenkinsopp, J., 2000, Isaiah 1-39, Doubleday, New York. (AB 19).

Brueggemann, W., 1998, Isaiah 1-39, Westminster Bible Companion, Westminster John Knox, Louisville. (Westminter Bible Companion).

Childs, B.S., 2001, Isaiah, Westminster John Knox, Louisville. (OTL).

Christensen, D.L., 2002, Deuteronomy 21:10-34:12, Thomas Nelson, Nashville. (WBC $6 \mathrm{~B})$.

Fichtner, J., 1949, 'Jesaja unter den Weisen', Theologische Literaturzeitung 74(2), 75-80.

Heschel, A.J., 2001 [1962], The prophets, Harper-Collins Publishers, New York.

Jensen, J., 2006, Ethical dimensions of the prophets, Liturgical Press, Collegeville.

Kaiser, O., 1981, Das Buch des Propheten Jesaja: Kapitel 1-12, Vandenhoeck \& Ruprecht, Göttingen. (ATD 17).

Lange, A., 2005, 'Weisheitsliteratur (AT)', in H.D. Betz et al. (eds.), Religion in Geschichte und Gegenwart (RGG), vol. 8, pp. 1366-1369, Mohr Siebeck, Tübingen.

Leclerc, T.L., 2001, Yahweh is exalted in justice: Solidarity and conflict in Isaiah, Fortress Press, Minneapolis.

Levin, C., 2006, Das Alte Testament, C.H. Beck, München.

O'Kane, M., 1991, 'Wisdom influence in First Isaiah', Proceedings of the Irish Biblical Association 14, 64-78.

O'Kane, M., 1996, 'Isaiah: a prophet in the footsteps of Moses', Journal for the Study of the Old Testament 69, 29-51. doi: 10.1177/030908929602106903

Oswalt, J.N., 1988, The book of Isaiah: Chapters 1-39, Eerdmans, Grand Rapids. (NICOT).

Otto, E., 1991, 'Ethik (AT)', in M. Görg \& B. Lang (eds.), Neues Bibel-Lexikon, vol. I, pp. 608-610, Benziger Verlag, Zürich.

Otto, E., 1995, 'Of aims and methods in Hebrew Bible ethics', Semeia 66, 161-172.

Otto, E., 1999, 'Ethik (AT)', in H.D. Betz et al. (eds.), Religion in Geschichte und Gegenwart (RGG), vol. 2, pp. 1603-1606, Mohr Siebeck, Tübingen.

Otto, E., 2004, 'Law and Ethics', in S.I. Johnson (ed.), Religions of the ancient world: A guide, pp. 84-97, Harvard University Press, Cambridge.

Otto, E., 2006, 'Old and new covenant. A post-exilic discourse between the Pentateuch and the book of Jeremiah. Also a study of quotations and allusions in the Hebrew Bible', Old Testament Essays 19(3), 939-949.

Otto, E., 2007a, 'Myth and Hebrew ethics in the Psalms', in D.J. Human (ed.), Psalms and mythology, (Library of the Hebrew Bible/Old Bible Studies 462), pp. 26-37, T\&T Clark, London.

Otto, E., 2007b, 'Welcher Bund ist ewig? Die Bundestheologie priesterlicher Schriftgelehrter im Pentateuch und in der Tradentenprophetie im Jeremiabuch', in C. Dohmen \& C. Frevel (eds.), Für immer verbündet: Studien zur Bundestheologie der Bibel. FS. F.-L. Hossfeld (SBS 211), pp. 161-169, Katholisches Bibelwerk, Stuttgart.

Otto, E., 2009, 'Moses Abschiedslied in Deuterononomium 32: Ein Zeugnis der Kanonsbildung in der Hebräischen Bibel', in E. Otto (ed.), Die Tora. Studien zum Pentateuch. Gesammelte Schrifte (BZAR 9), pp. 641-678, Harrassowitz, Wiesbaden.

Sæbø, M., 1998, 'Reflections on Old Testament ethics: Its dual character and its modern application', in M. Sæbø (ed.), On the way to Canon: Creative tradition history in the Old Testament, (JSOT suppl. ser. 191), pp. 162-181, Sheffield Academic Press, Sheffield.

Schwienhorst-Schönberger, L., 2006a, 'Das Buch der Sprichwörter', in E. Zenger (ed.), Einleitung in das Alte Testament, pp. 371-379, Kohlhammer, Stuttgart.

Schwienhorst-Schönberger, L., 2006b, 'Ethik: Theologisch. Biblisch', in W. Kasper et al. (eds.), Lexikon für Theologie und Kirche (LThK), vol. 3, pp. 908-909, Herder, Freiburg.

Sommer, B.D. 1998, A Prophet Reads Scripture: Allusion in Isaiah 40-66, University Press, Stanford. (Contraversions).

Steck, O.H., 1991, Der Abschluß der Prophetie im Alten Testament: Ein Versuch zur Frage der Vorgeschichte des Kanons, Neukirchener Verlag, Neukirchen-Vluyn. (BThS 17).

Sweeney, M.A., 1996, Isaiah 1-39 with an introduction to prophetic literature, Eerdmans, Grand Rapids. (FOTL 16).

Whedbee, J.W., 1971, Isaiah and wisdom, Abingdon Press, New York.

Williamson, H.G.M., 2006, Isaiah 1-5, T\&T Clark, London/New York. (ICC).

Wilson, L., 2009, 'Wisdom in Isaiah', in D.G. Firth \& H.G.M. Williamson (eds.) Interpreting Isaiah: Issues and approaches, pp. 145-167, Apollos, Nottingham.

Wright, C.J.H., 2004, Old Testament ethics for the people of God, Intervarsity Press, Leicester.

Zenger, E., 2006, 'Eigenart und Bedeutung der Weisheit Israels', in E. Zenger (ed.), Einleitung in das Alte Testament, pp. 329-334, Kohlhammer, Stuttgart. 